\title{
MEMOIRS
}

\section{JOHN FARRANT BUNFORD}

John FARRANT BUNFORD, former chicf executive of National Provident Institution and an eminent actuary, died on S July 1992, aged 91 . He was born on 4 June 1901.

John Bunford will be remembered especially for leading the return of the Institute of Actuaries to Staple Inn in 1955, following the skilful restoration of the original building, devastated by bomb damage in August 1944. The celebration was attended by actuaries world-wide, and his capabilities in orchestrating and hosting the occasion, coupled with his unique charm and humour, ensured its success. It was fitting that he should be the first President to wear the coveted badge of office-a gift from former Presidents-and the one to obtain the Institute's Grant of Arms.

He was educated at Christ's Hospital and St Catherine's College, Cambridge. His early actuarial career was spent at the Scottish Amicable and, later, the Royal Exchange Assurance, where he qualified as a Fellow in 1930. Two years later he joined NPI, and succeeded Henry Melville as Manager and Actuary in 1947. He retired from executive duties in 1964, and continued as a nonexecutive director until 1985. His stewardship covered the difficult years of post-war development, a period of substantial change and expansion of life insurance and pensions business. The growth of NPI's business during that time led him inevitably to redeveloping the company's century-old head oflice in the City, and to the commencement shortly afterwards of its Tunbridge Wells administration-itself one day to become the head oflice, as well as the town's largest single employer outside the public sector.

His business career was punctuated by high office in the life insurance industry, including chairmanship of the Life Oflices Association and of the Investment Protection Committee of the then British Insurance Association. While President of the Institute of Actuaries in 195456 he frequently represented the profession abroad, notably at the 50th anniversary celebrations of the Norwegian, Swedish and Swiss Actuarial Societies. The Faculty of Actuaries in Scotland elected him an Honorary Fellow at its centenary in 1956.

At home, Hurst Green, he became involved in Church and community activities. Unsurprisingly, he was drawn into planning and fundraising activitics for the extension of the local church, where he was chairman of the development committec. After moving to Liphook in his later years, he maintained his active interest in the Church, and became founder chairman of the local branch of the Imperial Cancer Research Fund. He was also a donations governor of his old school, Christ's Hospital.

He was a truly gentle man, balanced in judgement, but resolute in following it through. His office door was always open, as if to emphasise his approachability and his interest in others, which remained to the end.

His wife, Penelope, predeceased him. He is survived by 2 sons and a daughter.

G.V.B.

\section{JAMES BASIL HOLMES PEGLER}

James Basil Holmes Pegler died on 22 September 1992, little more than a month after his eightieth birthday. The high point of his long and dedicated service to the Institute was his Presidency from 1968 to 1970 . He was a man of wide cultural interests who, in his Presidential Address, surprised his audience with literary quotations in French, Italian and Russian as well as several in English. In that address he suggested ". . . that a serious interest in some cultural field unconnected directly with one's professional responsibility is a major factor in promoting the ability to form balanced judgements in that responsibility." He ended with a plea that "cncouragement might be given to cven wider cultural interests, to the benefit of the profession generally". 
Jim Pegler served for 25 years as the chief executive of Clerical Medical, first as General Manager and Actuary, and later as Managing Director. That appointment was the cornerstone of a most distinguished career, in the course of which he achieved the 'double' of the Chairmanship of the I ife Offices' Association and, later, of course, the Presidency of the Institute. Of his many other business and professional achievements his work for European insurance stands out. He was for some years Chairman of the Life Working Group of CEA (Comité Furopéen des Assurances).

To one who knew him well, Jim Pegler always seemed to be an academic al heart. His acadenic brilliance was combined with a shrewd business sense and an infinite capacity for taking pains. He began his business career and entered his actuarial training straight from Charterhouse. It was always a matter of regret to him that he did not go to university. It was therefore typical that, in his sixties and nearing retirement, he read for a degree at the Open University, and this just as he was about to be made a professor.

He was Investment Secretary of Clerical Medical before he succeeded Sir Andrew Rowell as General Manager in 1950 at the early age of 38 . It was in 1948 that he subnitted to the Institute his notable paper on 'The Actuarial Principles of Investment', in which he replaced the established Bailcy's Canons, which focused on security of capital, with Pegler's Principles, oversimplificd in the phrase "Look after the income, and the capital will look after itself." It is no exaggeration to say that he modernised, indeed revolutionised, the investment thinking of many of Britain's life offices.

He exemplified the Institute's motto "I hold every man a debtor to his profession. . . .". Everything he undertook, whether for the Institute, the LOA, the CEA, or for his employer, was carried through with extreme thoroughness and total intellectual integrity. He was uncompromising when he thought he was right, and hardly knew the meaning of the word 'expediency'. One of the several Chairmen under whom he served was similarly uncompromising. As there were many matters on which they disagreed, their relationship was somewhat stormy, and, to say the least, interesting to those watching from the fringe of the discussions.

After his retirement in 1975 from his executive role with Clerical Medical, he served as a nonexecutive director for 8 years, but the main focus of his actuarial life became City University. It was a source of great pleasure to his friends, as well as to Jim himself, when he was asked to succed his old friend Bernard Benjamin as Professor of Actuarial Science, and his love of teaching, which some older members of the profession may still remember from his service as a tutor soon after the Second World War, was given full scope. Bernard, Jim's predecessor, and Steven llaberman, his successor at City, tell of his determination to understand the new world into which he had entered, and to make good any shortcomings which might have arisen from his unorthodox cntry into university life. He had to build on the foundations laid by Bernard, and he played a major role in the development of the practical teaching structure to serve the early intakes of students. Twice he visited Nigeria, secking to help the establishment of actuarial studies there. His enthusiasm for teaching was further demonstrated when, after he had passed the Chair to his successor, he continued as a visiting. professor at City, and also taught mathematics with marked success at a comprehensive school in Dorking.

Many will remember Jim for his energy, brought home to them in a practical way if they accepted a challenge to a game of squash, or were tempted to try to keep pace with him as he walked from a meeting to a dinner. In his sixties he played in a football match at City between staff and students. Even when, well into his seventies, he gave up squash, he still felt the need of exercise and took up tap dancing instead.

Jim was a good companion, a force amongst actuaries and life assurance people, and a man whose regard for the truth never wavered. He leaves a widow, Enid, three daughters and a son, and we, like them, are the poorer for his passing.

L. G. HALL, 